1 кандидат педагогічних наук, доцент кафедри МНМ та MHI, ДВНЗ «ДДПУ» e-mail: besedin_boris@ukr.net, ORCID 0000-0003-2157-5252

2 студент 4 курсу фізико-математичного факультету, ДВНЗ «ДДПУ» e-mail: gaydar.sergiy.1999@gmail.com, ORCID 0000-0001-7448-5037

\title{
ШЛЯХИ ВДОСКОНАЛЕННЯ УЗАГАЛЬНЕННЯ ТА СИСТЕМАТИЗАЦЇ̈ ЗНАНЬ ПРИ ВИВЧЕННІ АЛГЕБРИ В 7-9 КЛАСАХ
}

Стаття присвячена проблемі узагальнення та систематизації знань учнів при вивченні курсу алгебри 7-9 класів, необхідності вдосконалення методики навчання математики та розробці методичних рекомендацій щодо вирішення цієї проблеми.

Ключові слова: узагальнення, систематизація, комп'ютер, IKT.

\section{Вступ}

На сучасному етапі розвитку педагогічної науки і шкільної практики особливого значення набуває проблема організації навчальної діяльності школярів та розробки нового змісту та нових технологій навчання і виховання, адже в системі освіти України взято курс на гуманізацію та демократизації навчання, де формування особистості та компетентності учнів виходить на перший план. Видатні педагоги зазначали важливість узагальнення та систематизації знань, наприклад Я.А. Коменський стверджував: «Все повинно здійснюватися так послідовно, щоб сьогоднішне закріплювало вчорашне і торувало шлях до завтрашнього» [3]. Аналіз контрольних робіт, відповідей учнів свідчить про не достатню систематизованість знань. Певна частина вчителів не займається цією проблемою на необхідному рівні, інші розуміють систематизацію досить своєрідно, зводячи їі до організації уроків узагальнюючого повторення. I навіть узагальнююче повторення дуже часто підміняеться простим повторенням матеріалу, в процесі якого учні розв'язують вправи безпосередньо взяті із відповідних контрольних робіт.

Нові тенденції в розвитку системи неперервної освіти вимагають приділення належної уваги саме формуванню вмінь засвоювати та використовувати інформацію, оволодіванню учнями механізмом мислення, що дасть можливість творчо підійти до розв'язання поставлених перед учнями проблем. Серед загальних прийомів розумової діяльності учнів важливе значення мають систематизація та узагальнення, що здатні забезпечити активну і самостійну 
теоретичну та практичну діяльність учнів в цілісному педагогічному процесі. Оскільки необхідність систематизації та узагальнення при навчанні математики зумовлюється характером самої науки математики, то по цій причині в критеріях оцінювання навчальних досягнень з математики в системі загальної середньої освіти, рекомендованих Міністерством освіти і науки України, характеристикою високого рівня навчальних досягнень учня (необхідних для одержання найвищого бала) є вміння узагальнювати і систематизувати набуті знання. Одним із шляхів забезпечення умов для досягнення кожним учнем необхідного рівня знань умінь і навичок з математики є поєднання традиційних та інноваційних технологій навчання і виховання

\section{Основна частина}

В процесі узагальнення і систематизації знань переслідується мета встановлення як внутрішніх зв'язків засвоєної системи знань, так і зовнішніх, міжсистемних зв'язків на основі попередньо вивченого матеріалу. При цьому є доцільним індуктивний підхід, від окремого до загального, який передбачає: ознайомлення учнів з темою, цілями та завданнями; мотивацію навчання; відтворення здобутих знань; узагальнення та систематизацію їх із встановленням внутрішньо-системних та зовнішньо системних зв'язків, тощо.

Методика систематизації та узагальнення знань передбачає підготовку у вигляді накреслення плану проведення, системи наочності, визначення характеру та обсягу завдань, що будуть надаватися учням.

Систематизація математичних знань являє собою процес встановлення зв'язків між математичними поняттями, їх властивостями (судженнями), способами розв'язування завдань з метою утворення системи знань. Завдяки систематизації знань учні глибше усвідомлюють, запам'ятовують, використовують у навчанні та майбутній професійній діяльності основні математичні ідеї та операційні навички, тому систематизація може стати для них методом поглибленого вивчення математичних об’єктів [5].

Шкільний курс алгебри характеризується підвищенням теоретичного рівня навчання, поступовим посиленням ролі теоретичних узагальнень і дедуктивних висновків. Прикладна спрямованість курсу забезпечується систематичним зверненням до прикладів, що розкривають можливості вживання математики до вивчення дійсності і вирішення практичних завдань [1].

Застосування доцільних інформаційних технологій сприяє кращому усвідомленню учнями функціонально-морфологічних компонентів системи математичних знань, а саме елементів системи, зв'язків між елементами системи та зовнішнім середовищем, системної властивості та функціі, а також рівня 
ієрархії системи. Це досягається за рахунок спеціального відбору змісту навчального матеріалу, що підлягає систематизації, групування його особливим чином (структурні схеми, таблиці, діаграми тощо), проведення розрахунковографічних експериментів під керівництвом вчителя, а також під час самостійної частково-пошукової роботи учнів у колективних та індивідуальних навчальних проектах, присвячених систематизації математичних знань [4].

Основним видом використання комп'ютерно-орієнтованих засобів навчання є їх органічна інтеграція в певні теми занять. Учні опановують комп'ютерні програми, набувають навичок користування пристроями введеннявиведення, уміння й навички управління комп'ютером та одночасно удосконалюють свої знання з предмету, розвивають пам'ять, просторову уяву, логічне мислення, творчі здібності.

Тож, завданнями застосування комп'ютера при вивченні курсу алгебри є:

- забезпечення зворотного зв'язку в процесі навчання;

- підвищення унаочнення навчального процесу;

- пошук інформації із різноманітних джерел;

- індивідуалізація навчання;

- моделювання досліджуваних процесів або явищ;

- організація колективної та групової роботи;

- здійснення контролю за навчальними досягненнями [2].

Комп'ютер при вивченні курсу алгебри розглядається як потужний дидактичний засіб, який включає дітей до активної праці, підвищує їхній інтерес до навчання, сприяє кращому засвоєнню матеріалу і підвищує ефективність навчання.

Таким чином, по мірі вивчення математики в сучасній школі необхідність систематизації та узагальнення знань значно зростає. Без впровадження в навчальний процес IKT неможливо досягнути тих цілей, які ставить школа в навчанні математиці. Сформулюємо основні положення систематизації та узагальнення знань при вивченні алгебри 7-9 класів у сучасній школі:

- Систематизація знань має відбуватися не тільки на заключному етапі вивчення окремої теми. Така робота має проводитися на різних етапах вивчення теми. Основу систематизації знань учнів повинне складати створення цілісних уявлень про лінії алгебри 7-9 класів з обов'язковим включенням цих знань до системи знань з математики у цілому.

- Використання узагальнюючих схем, таблиць та інших засобів наочності сприяе формуванню в учнів системи знань. Необхідно включити до шкільної програми можливість роботи з пакетами комп'ютерних програм 3 
алгебри. Використання комп'ютерних програм при вивченні курсу алгебри розвиває інтерес до вивчення предмета, підвищує ефективність самостійної роботи учнів, індивідуалізацї процесу навчання шляхом: покращення наочності навчання, сприяння формуванню абстрактних уявлень про математичні моделі, поглиблення самостійності вивчення курсу, створення комфортних умов проведення різних форм контролю знань, що допомагає в розробці індивідуальних заходів для корекцї знань учнів у межах досягнення визначених цілей навчання.

- Систему вправ підручників доцільно поповнити питаннями і завданнями систематизуючого характеру, які можна буде виконувати за допомогою пакетів програм, націлених на вивчення алгебри. Доцільно пропонувати учням вправи спрямовані на узагальнення і конкретизацію алгебраїчних понять, які можна виконувати за допомогою різноманітних програмних засобів. При виконанні вправ такого виду учню необхідно із усіх засвоєних ним раніше алгебраїчних знань відібрати необхідні для розв'язання даної задачі, застосувати вміння роботи з комп'ютером та програмою та застосувати найбільш зручний алгоритм розв'язання даної вправи.

\section{Висновки}

Узагальнення і систематизація знань на уроках математики є важливим і необхідним етапом у процесі формування знань, вмінь, і навичок. За допомогою узагальнення учні встановлюють загальні та істотні ознаки вивчених предметів, явищ, процесів і переходять від вузьких понять до більш загальних і широких.

Використання комп'ютера у сучасній школі дає можливості для вдосконалення традиційних методів навчання, роблячи їх більш ефективним. Завдяки збагаченню традиційної методики систематизації знань педагогічнодоцільними комп'ютеризованими засобами навчання відбувається виділення і закріплення в свідомості учнів функціонально-морфологічних компонентів системи математичних знань.

Розроблені і апробовані на практиці експериментальні комп'ютерноорієнтовані дидактичні засоби систематизацї знань (комп'ютерні презентації відповідної тематики, класифікаційні схеми, діаграми, тощо) формують готовність учнів використовувати засвоєні знання і способи діяльності в житті для розв'язання завдань практичного і теоретичного змісту. Обгрунтоване використання ПК сприяє розвитку розумових здібностей дітей, їхньому творчому мисленню в розв'язанні завдань з математики, підвищує інтерес до навчання, сприяе набуттю знань і вмінь. 


\section{Література}

1. Беседін Б.Б., Пономаръова А.О. Узагальнення та систематизація знань при вивченні алгебри 7-9 класів. Збірник наукових праць фізикоматематичного факультету ДДПУ. 2013. Випуск 3. С. 140-144.

2. Жалдак M.I. Комп'ютер на уроках математики. Посібник для вчителя. К. : Техніка, 1997. 303 с.

3. Коменсъкий Я.А. Вибрані педагогічні твори. Під ред. Піскунова О.І. та ін. М. : Педагогіка, 1982, 655 с.

4. Марченко O.M. Систематизація знань учнів у процесі навчання математики із застосуванням методу проектів на основі комп'ютерної підтримки. Дидактика математики: проблемы и исследования. 2006. №26. C. $150-154$.

5. Монахов B.M. Что такое новая информационная технология обучения? Математика в школе. 1990. №2. С. 47-52.

\section{Besedin B.B., Gaydar S.O.}

Donbas State Pedagogical University, Sloviansk, Ukraine.

\section{Ways to improve the generalization and systematization of knowledge in the study of algebra in grades 7-9}

The article is devoted to the problem of generalization and systematization of students' knowledge when studying the course of algebra of 7-9 grades, the need to improve the methodology of teaching mathematics and the development of guidelines for solving this problem.

Keywords: generalization, systematization, computer, ICT. 